DOI 10.37882/2223-2974.2020.11.08

\title{
ТРЕБОВАНИЯ К ДОСТАТОЧНОСТИ СОБСТВЕННОГО КАПИТАЛА КРЕДИТНОЙ ОРГАНИЗАЦИИ И ЕГО ВЛИЯНИЕ НА ПОТЕНЦИАЛ РОССИЙСКИХ БАНКОВ
}

\section{CAPITAL ADEQUACY REQUIREMENTS OF A CREDIT INSTITUTION AND ITS IMPACT ON THE POTENTIAL OF RUSSIAN BANKS \\ V. Golovanov}

Summary: The Requirement for banks to have a minimum amount of equity capital is established at the legislative level and is due to the fact that banks assume various risks in the course of their activities and may incur losses if such risks materialize. At the same time, banks' coverage of risks from their own capital is subject to the General rule: the greater the risks, the more capital is required to cover them. This suggests that banks ' compliance with the minimum equity requirements is not sufficient to ensure their effective functioning in the financial market. In order for a Bank to function effectively in the financial market, it is necessary that the amount of the Bank's equity capital is not just minimal, but sufficient to cover possible losses, which is why it is so important that banks constantly assess the risks they are exposed to and the losses they may incur in order to assess their potential. In the article, the author examines the requirements for the equity capital adequacy of a credit institution established by the international standards Basel I, Basel II and Basel III, and assesses their impact on the potential of Russian banks.

Keywords: equity, Bank, loss coverage, minimum capital, risks, tier 1 capital, tier 2 capital, potential of banks.
Аспирант, Финансовьй университет при Правительстве Российской Федерации, г. Москва golovanovvs@yandex.ru

Аннотация: Требование о наличии у банков минимального размера собственного капитала установлено на законодательном уровне и обусловлено тем, что банки в рамках осуществления своей деятельности берут на себя различные риски и могут понести убытки, если такие риски материализуются. При этом покрытие банками рисков за счет собственного капитала подчинено общему правилу - чем больше риски, тем больше капитала требуется для их покрытия. Сказанное дает основание предполагать, что соблюдение банками требований в отношении наличия минимального размера собственного капитала недостаточно для того, чтобы обеспечить свое эффективное функционирование на финансовом рынке. Для того, чтобы функционирование банка на финансовом рынке было эффективным, необходимо, чтобы размер собственного капитала банка был не просто минимальным, а достаточным для покрытия возможных убытков, поэтому так важно, чтобы банки постоянно оценивали риски, которым они подвержены, и убытки, которые они могут понести. Это необходимо для того, чтобы оценить свой потенциал. В статье автором рассматриваются требования к достаточности собственного капитала кредитной организации, установленные международными стандартами Базель I, Базель II и Базель III, и оценивается их влияние на потенциал российских банков.

Ключевые слова: собственный капитал, банк, покрытие убытков, минимальный размер капитала, риски, капитал 1- уровня, капитал 2-уровня, потенциал банков.

ственные ценные бумаги и процентные кредиты (например, ипотечные кредиты, аккредитивы и межбанковские кредиты). Обязательства банка (то есть пассивная часть его капитала) включает в себя резервы на возможные потери по ссудам и любые задолженности, которые имеет банк. В случае, если банк решит ликвидировать свои активы, то размер его обязательств должен быть покрыт из средств собственного капитала.

Из сказанного можно сделать вывод о том, что эффективность функционирования банка на финансовом рынке определяется не тем, что собственный капитал банка должен отвечать требованиям к минимальному размеру, а тем, что он должен быть такого размера, которого будет достаточно для покрытия возможных убытков. Именно поэтому на законодательном уровне кроме требований к минимальному размеру собственного капитала банка устанавливаются также требования к общему уровню достаточности капитала и особенностям его формирования. Цель законодательных требований 
к достаточности собственного капитала у банков состоит в установлении того, чтобы банки имели достаточно капитала в резерве, чтобы справиться с определенной суммой убытков, прежде чем наступит их неплатежеспособность $[3,7,8]$.

В Российской Федерации основная банковская нормативная база, в которой установлены требования к достаточности собственного капитала банка, состоит из международных стандартов, принятых международным комитетом, созданным для разработки стандартов банковского регулирования - Базельским комитетом по банковскому надзору (BCBS) (далее - Базельский комитет), норм федерального законодательства Российской Федерации в сфере банков и банковской деятельности [1], а также нормативных документов основного регулятора банковской деятельности в Российской Федерации - Центрального банка Российской Федерации (далее ЦБ РФ).

Международные стандарты Базельского комитета являются той основной, которая обеспечивает определение российскими банками достаточного размера собственного капитала для поддержания своего потенциала. При этом наиболее важными из международных стандартов Базельского комитета являются Базель I, Базель II и Базель III, определяющие достаточность банковского капитала, за которым внимательно следят рыночные и банковские регуляторы. При этом из вышеперечисленных стандартов Базель III, как отмечает ЦФ РФ, является наиболее важным элементом политики Базельского комитета после мирового финансового кризиса 2008-2009 гг. и направлен на повышение устойчивости банковских систем в странах «Группы 20» [9], в том числе и в Российской Федерации.

Вместе с тем, итоговый набор регуляторных требований к банкам, включающий в себя все изменения Базеля III, а также пересмотренные подходы к оценке рыночного риска, внедрение которых изначально планировалось на 2019 год, в Российской Федерации планируется к вступлению в силу только в 2022 году [9].

Базель I, Базель II и Базель III - это определенные рекомендации международного уровня, которые разрабатывались Базельским комитетом по банковскому надзору в течение нескольких десятков лет, начиная с 1980-х годов. Согласно общим правилам Базель І, Базель II и Базель III, банки должны иметь определенное количество наличных денег и/или других ликвидных активов для выполнения своих обязательств. Международные стандарты Базель І, Базель II и Базель III, устанавливая требования к достаточности собственного капитала банков, делят такой капитал на уровни: капитал 1 уровня и капитал 2 уровня, а также определяют требования к коэффициенту достаточности капитала ((CAR) - отношение капитала к взвешенным по риску активам). При этом капитал 1-го уровня является основным показателем потенциала любого банка, поскольку дает представление о показателях финансовой устойчивости банка.

Капитал 1-го уровня - это основной капитал, по большей части состоящий из раскрытых резервов (нераспределенная прибыль) и обыкновенных акций. Он также может включать некумулятивные, не подлежащие возврату привилегированные акции. В рамках Базеля I, Базеля II собственный капитал может включать также инновационный инструменты, которые не могут быть погашены, однако такие инструменты должны соответствовать строгим условиям, а капитал, приобретенный с помощью этих инструментов, может составлять только 15\% от общего капитала банка 1-го уровня.

Когда положения Базеля III начнут применяться в полном объеме, банкам будет запрещено иметь в составе собственного капитала капитал, заработанный с помощью инновационных инструментов. Такой подход к недопущению наличия в составе основного капитала - капитала, полученного с помощью инновационных инструментов, обусловлен необходимостью устранения недостатков в финансовом регулировании, выявленных мировым финансовым кризисом в 2007 и 2008 годах.

Теперь акцентируем внимание на коэффициенте достаточности собственного капитала 1-го уровня (RWA). Такой коэффициент предназначен для сравнения собственного капитала банка с его совокупными активами, взвешенными по риску.

Исходя из значимости и содержания капитала 1-го уровня для банка можно сделать однозначный вывод о том, что капитал 1-го уровня является основным источником финансирования банка, обеспечивающим его потенциал. Как правило, в нем хранятся почти все накопленные банком средства. Иными словами, капитал 1-го уровня - это средства, генерация которых имеет основную главную цель - поддержку банка тогда, когда банк должен погасить убытки, не прекращая своей деятельности.

Согласно текущей версии Базеля III, минимальный коэффициент достаточности капитала составляет 6\%. Этот коэффициент рассчитывается путем деления капитала 1-го уровня на его совокупные активы, основанные на риске. При этом, согласно требованиям нормативных актов ЦБ РФ, для российских банков, пока положения Базеля III не вступили в силу, минимальный коэффициент достаточности капитала 1-уровня составляет 9,3\%.

Теперь акцентируем внимание на капитале 2-уровня. Термин капитал 2-го уровня относится к одному из компонентов обязательных резервов банка. Уровень 2 
определяется как второй или дополнительный уровень капитала банка и состоит из таких статей формирования, как резервы переоценки, гибридные финансовые инструменты и субординированный срочный долг. Он считается менее безопасным для банка, чем капитал 1-уровня. Поэтому капитал 2- уровня еще называют дополнительным капиталом. Коэффициент достаточности такого капитала рассчитывается путем его деления на совокупные активы, основанные на риске. Наряду с капиталом 1-го уровня, капитал 2-уровня обеспечивает банку финансовую подушку на случай, если ему потребуется ликвидировать свои активы.

Рассмотрим более подробно статьи формирования капитала 2-уровня. Резервы переоценки представляют собой резервы, созданные в результате переоценки актива. Типичным примером резерва переоценки является здание, принадлежащее банку. Если со временем стоимость объекта недвижимости имеет тенденцию к росту, то она может быть переоценена. Общие резервы, формирующие капитал банка 2-уровня, - это те убытки, которые банк может иметь, но пока еще не имеющие полной количественной оценки, в том числе убытки от непогашенных кредитов. Общая разрешенная сумма общего резерва составляет 1,25\% от активов банка, взвешенных по риску (RWA). Гибридные инструменты капитала представляют собой совокупность долговых и долевых инструментов (что и определяет их обозначение в качестве «гибридных»). Примером гибридного инструмента можно назвать привилегированные акции. При этом необходимо отметить, что существуют определенные правила в части включения гибридных инструментов в капитал банка 2-уровня. Так, банк может включать гибридные инструменты в свой капитал 2-уровня только в том случае, если активы, входящие в такие инструменты, по содержанию схожи с собственным капиталом банка для того, чтобы убытки могли быть приняты на номинальную стоимость инструмента.

Четвертой статьей формирования капитала 2-уровня является субординированный долг. Такой долг будет субординированным по отношению к обычным банковским вкладам, кредитам и ценным бумагам, которые составляют более значимый долг банка. Минимальный первоначальный срок субординированного долга составляет пять лет и более.

Капитал 2-уровня дифференцируется на два уровня: верхний и нижний (в зависимости от ценности для банка). Капитал верхнего уровня состоит из бессрочных ценных бумаг, то есть бумаг, не имеющих срока погашения, резервов переоценки и инвестиций в основной капитал. Капитал нижнего уровня - это субординированный долг, как правило не связанный с высокими затратами и потерями банка.
Таким образом, в целом собственный капитал банка можно рассматривать как балансовую стоимость активов на балансе банка, достаточность которых обеспечивает банку возможность покрывать убытки от потерь, не прекращая совей деятельности. Законодательно установленные требования в отношении достаточности собственного капитала имеют большое практическое значение для потенциала российских банков, поскольку нормативы достаточности капитала показывают размер финансовой «подушки», необходимой для покрытия разумной суммы убытков до того, как банки станут неплатежеспособными и, следовательно, потеряют средства вкладчиков.

При этом необходимо отметить, что требования к достаточности собственного капитала направлены не только на поддержание платежеспособности банков, но и на поддержание всей финансовой системы в стране в целом. В эпоху глобализации национальных и международных финансов все финансовые процессы взаимосвязаны и крах одного банка в пределах страны может затронуть другие банки.

Тем не менее, требования к достаточности собственного капитала банков имеют своих критиков, утверждающих, что такие требования в целом снижают потенциал банков. Так, в некоторых исследованиях акцентируется внимание на том, что высокие требования к капиталу потенциально могут привести к снижению банковского риска и конкуренции в финансовом секторе (на том основании, что регулирование всегда оказывается более дорогостоящим для небольших учреждений, чем для крупных). Снижение уровня конкуренции в банковском секторе можно наблюдать в Российской Федерации в последние 8 лет. При этом у некоторых банков лицензия отзывается в том числе по причине игнорирования основных требований к капиталу [11].

В других источниках отмечается, что требование к достаточности собственного капитала банка обязывает банки сохранять определенный процент ликвидности активов и может препятствовать способности учреждений инвестировать и зарабатывать деньги, что в свою очередь влияет на возможность банков предоставлять кредиты клиентам, а поддержание определенного уровня капитала еще и увеличивает издержки, что в свою очередь увеличивает затраты на заимствование или другие услуги для потребителей [4].

Вместе с тем, противники требований к достаточности банковского капитала забывают о том, что само появление таких требований связано с наличием большого количества обманутых вкладчиков и неспокойного инвестиционного климата, вызванных слишком лояльным банковским регулированием, порождающим безответственное финансовое поведение крупных институ- 
тов, и как следствие финансового кризиса, краха рынка или рецессии.

Подводя итог, отметим, что потенциал российского банка, представляющий собой совокупность его стратегических ресурсов, определяющих границы финансовых возможностей, имеет прямую зависимость от размера собственного капитала банка, который должен соответствовать не только требованиям в отношении его минимального размера, но и быть достаточным для покрытия возможных убытков банка. Основополагающие требования к достаточности собственного капитала, применяемые к российским банкам в настоящий момент, установлены международными стандартами Базель I, Базель II и Базель III. Соблюдение таких требований имеет большое практическое значение для поддержания банковского потенциала, поскольку достаточный собственный капитал обеспечивает поддержку банка тогда, когда банк должен погасить убытки, не прекращая своей деятельности.

\section{ЛИТЕРАТУРА}

1. Федеральный закон от 02.12.1990 № 395-1 «0 банках и банковской деятельности» (с изм. и доп., вступ. в силу с 14.06.2020) // Собрание законодательства РФ. 1996. №6. Ст. 492.

2. Основы банковской деятельности (Банковское дело) / Под ред. К.Р. Тагирбекова. - М.: ИНФРА-М, Изд-Во «Весь мир», 2003. - С. 195.

3. Дорожкина Н.И., Федорова А.Ю. К вопросу о роли собственного капитала коммерческого банка как гаранта его стабильности // Социально-экономические явления и процессы. 2017. №3. С.28-33

4. Корнейчук В.И. Управление риском недостаточности собственных средств (капитала) кредитной организации // Финансовая аналитика: проблемы и решения. 2011. №5. С.21-28.

5. Никифорова В.Д. Достаточность собственного капитала как основа регулирования банковских рисков в России // Научный журнал НИУ ИтМО. Серия: «Экономика и экологический менеджмент». 2016. № 1. С. 40-46.

6. Рыкова И.Н., Фисенко Н.В. Кредитный потенциал коммерческого банка, его роль в деятельности банка и методология оценки // Финансы и кредит. 2005. №25 (193). С. 10-20.

7. Смольянинова Е.Н., Духанина Н.А., Дашидондокова А.Ц. Базель III В России: новые подходы к определению капитала // Фундаментальные исследования. 2014. № 12 (часть 3). С. 601-605

8. Татаринова Лариса Валентиновна К вопросу о достаточности капитала кредитной организации // Baikal Research Journal. 2016. №3. URL: https:// cyberleninka.ru/article/n/k-voprosu-0-dostatochnosti-kapitala-kreditnoy-organizatsii (дата обращения: 16.10.2020).

9. О сроках внедрения Базеля III. Прес-релиз Банка России. Официальный сайт Банка России URL: https://cbr.ru/press/pr/?file=06022018_120000ik2018-0206t11_55_45.htm (дата обращения: 16.10.2020).

10. РБК. За одно утро в России лицензий лишились четыре банка URL: https://www.rbc.ru/finances/24/07/2020/5f1a996e9a79474ae41ef0d0 (дата 0бращения: 16.10.2020).

( Голованов Владислав Сергеевич (golovanovvs@yandex.ru). 